\title{
Role of Munc18-1 in the biological functions and pathogenesis of neurological disorders (Review)
}

\author{
FAJUAN TANG ${ }^{1,2 *}$, DONGQIONG XIAO ${ }^{1,2^{*}}$, LIN CHEN $^{1,2}$, HU GAO $^{1,2}$ and XIHONG LI ${ }^{1,2}$ \\ ${ }^{1}$ Department of Emergency, West China Second University Hospital, Sichuan University; \\ ${ }^{2}$ Key Laboratory of Birth Defects and Related Diseases of Women and Children, Sichuan University, \\ Ministry of Education, Chengdu, Sichuan 610041, P.R. China
}

Received September 7, 2020; Accepted December 30, 2020

DOI: $10.3892 / \mathrm{mmr} .2021 .11837$

\begin{abstract}
The release of neurotransmitters following the fusion of synaptic vesicles and the presynaptic membrane is an important process in the transmission of neuronal information. Syntaxin-binding protein 1 (Munc18-1) is a synaptic fusion protein binding protein, which mainly regulates synaptic vesicle fusion and neurotransmitter release by interacting with soluble $\mathrm{N}$-ethylmaleimide sensitive factor attachment protein receptor. In addition to affecting neurotransmitter transmission, Munc18-1 is also involved in regulating neurosynaptic plasticity, neurodevelopment and neuroendocrine cell release functions (including thyroxine and insulin release). A number of previous studies have demonstrated that Munc18-1 has diverse and vital biological functions, and that its abnormal expression serves an important role in the pathogenesis of a variety of neurological diseases, including epileptic encephalopathy, schizophrenia, autism, Parkinson's disease, Alzheimer's disease, multiple sclerosis, Duchenne's muscular dystrophy and neuronal ceroid lipofuscinosis. The present review summarizes the function of Munc18-1 and its possible relationship to the pathogenesis of various neurological diseases.
\end{abstract}

Correspondence to: Dr Xihong Li, Department of Emergency, West China Second University Hospital, Sichuan University, 20 Renmin South Road, Chengdu, Sichuan 610041, P.R. China E-mail: lixihonghxey@163.com

*Contributed equally

Abbreviations: NARE, soluble N-ethylmaleimide sensitive factor attachment protein receptor; PKC, protein kinase C; SNAP25, synaptosomal-associated protein of $25 \mathrm{kDa}$; NSF, N-ethylmaleimidesensitive fusion; SNAP, soluble NSF-attachment protein; MECP2, methyl-CpG binding protein 2; SCZ, schizophrenia; AD, Alzheimer's disease; MS, multiple sclerosis; GABA, gammaaminobutyric acid

Key words: syntaxin-binding protein 1, epilepsy encephalopathy, neurotransmitter transmission, schizophrenia, neurodegenerative diseases

\section{Contents}

1. Introduction

2. Function of Munc18-1

2. Association between Munc18-1 and neurological disorders

3. Conclusion and future perspectives

\section{Introduction}

The release of neurotransmitter caused by the fusion of synaptic vesicles and the presynaptic membrane is an important process in the transmission of neuronal information (1). This process is regulated by a series of key proteins, including soluble $\mathrm{N}$-ethylmaleimide-sensitive factor attachment protein receptor (SNARE), protein transport protein Sec1 (Sec1)/ Mammalian uncoordinated (Munc) 18, N-ethylmaleimide sensitive factor (NSF), soluble NSF adaptor protein (SNAP), synaptotagmin-1 and Munc13, among others (2). SNARE protein is the core complex that establishes membrane fusion, which is mainly composed of SNAP25, vesicular-associated membrane protein and syntaxin-1. SNAP25 and syntaxin-1 form the target membrane of the vesicle protein (T-SNARE), which binds to the synaptic vesicle protein (3). SNARE complex assembly is an important step in the fusion process of synaptic vesicles and the presynaptic membrane (4). SNARE protein-mediated synaptic vesicle fusion and secretion are regulated by a variety of proteins, of which Sec1/ Munc18 (SM) serves an important role. Previous studies have revealed that the absence of the SM protein can inhibit membrane fusion in different systems, such as the endocrine and the vascular system (5-8).

The SM protein family is an indispensable regulatory protein for membrane fusion. It is a highly conserved polypeptide chain with a molecular weight of 60-70 kDa and a length of $\sim 600$ amino acids (9). The human genome contains 7 homologous SM proteins, of which syntaxin-binding protein (Munc18)-1, Munc18-2 and Munc18-3 are involved in secretion, with Munc18-1 being highly expressed in neurons and neuroendocrine cells (10). Munc18-1 is a synaptic fusion protein binding protein and is encoded by the syntaxin-binding protein 1 gene (STXBP1), which is located on chromosome 9q34.11 and contains 20 exons (11). The protein encoded 


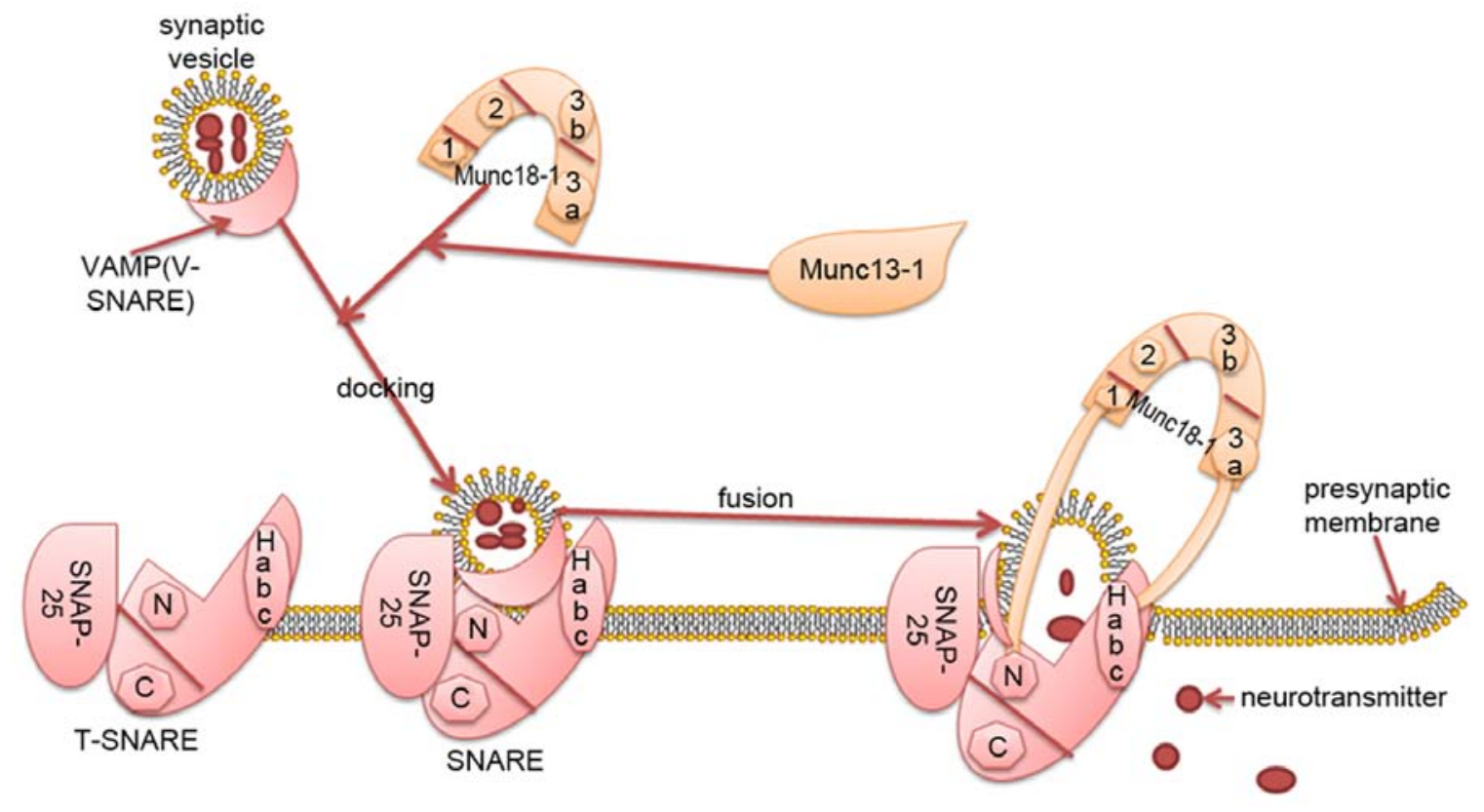

Figure 1. Munc18-1regulates neurotransmitter transmission by interacting with the SNARE complex. The SNARE protein is mainly composed of SNAP-25, vesicular-associated membrane protein and syntaxin1. SNAP-25 and syntaxin1 form the target membrane of vesicle protein (T-SNARE), which binds to synaptic vesicle protein (VAMP). Munc18-1 has a complex, arched, tertiary structure. The arch consists of four closely connected domains named 1, 2, 3a and 3b. Domain 1 and 3a form an arched gap. Syntaxin-1 is the core protein of SNARE. Munc18-1 primarily regulates vesicle fusion by interacting with syntaxin-1 (Habc domain; N-terminal short peptide). Domain 3a is in close contact with the Habc domain of syntaxin-1, domain 1 is located on the other side of the arched gap and binds to the N-terminal short peptide of syntaxin-1. Munc13-1 bridges synaptic vesicles and presynaptic membrane fusion to coordinate the assembly of SNARE with Munc18-1. Munc18-1 regulates vesicle docking and fusion by interacting with the SNARE complex, affects the released vesicles and participates in the transmission of neurotransmitters. Munc, mammalian uncoordinated; SNARE, soluble N-ethylmaleimide-sensitive factor attachment protein receptor; SNAP25, synaptosomal-associated protein of $25 \mathrm{kDa}$; T-SNARE, target membrane of soluble N-ethylmaleimide-sensitive factor attachment protein receptor; V-SNARE, synaptic vesicle protein of soluble N-ethylmaleimide-sensitive factor attachment protein receptor; VAMP, vesicular-associated membrane protein; N, N-terminus; C, C-terminus; 1, domain 2; 2, domain 2; 3a; domain 3a; 3b, domain 3b.

by the STXBP1 gene is highly conserved in evolution. The occurrence of missense, nonsense, frameshift and splicing mutations can lead to insufficient protein haploids, impaired protein stability and cortical excitation imbalances that affect learning and memory (12-14).

Syntaxin-1 is the core protein of SNARE and Munc18-1 primarily regulates vesicle fusion by interacting with syntaxin-1 (Habc domain; N-terminal short peptide) (15). The tertiary structure of Munc18-1 is complex, exhibiting an arched structure, consisting of four closely connected domains named 1, 2, 3a and $3 \mathrm{~b}$ (domains 1, 2, 3a and $3 \mathrm{~b}$ form the arch), domains 1 and $3 \mathrm{a}$ form an arched gap, domains 3a contacts with the Habc of syntaxin-1. Domain 1 is located on the other side of the arched gap and binds to the N-terminal peptide of syntaxin-1 (Fig. 1) (16).

\section{Function of Munc18-1}

Munc18-1 regulates neurotransmitter transmission by interacting with the SNARE complex. Munc18-1 promotes or inhibits the assembly of the SNARE complex primarily by combining with syntaxin-1 (Habc domain; N-terminal short peptide) in the 'open' and 'closed' conformations (17). Munc18-1 regulates vesicle fusion by interacting with the SNARE complex, affects the number of vesicles released and the supply of vesicles, and participates in the transmission of various neurotransmitters, including dopamine, glutamate and $\gamma$-aminobutyric acid (GABA) (Fig. 1) $(18,19)$.
Previous studies have demonstrated that the N-terminal peptide and Habc domain of syntaxin-1 serve an important role in synaptic vesicle fusion. The N-terminal peptide is essential for vesicle fusion itself, whilst the Habc domain regulates this fusion by forming a closed syntaxin-1 conformation (20,21). The current hypothesis is that Munc18-1 and syntaxin-1 have several binding modes: i) Munc18-1 binds to syntaxin-1 (via the Habc domain) in a 'closed' conformation, stabilizing the conformation of syntaxin-1 and inhibiting the assembly of the SNARE complex (16); ii) Munc18-1 combined with 'closed' conformation syntaxin-1 serves as a template for SNARE assembly, with Munc13-1 helping to open the syntaxin-1 'closed' conformation. Munc13-1 Bridges synaptic vesicles and presynaptic membrane fusion, and Munc18-1 and Munc13-1 coordinate the assembly of the T-SNARE complex together in an NSF-SNAP resistant manner (22); and iii) Munc18-1 combined with the 'open' conformation ofsyntaxin-1 (N-terminal short peptide) initiates and stimulates SNARE-mediated membrane fusion (16). The regulatory mechanism of Munc18-1 is complex, involving promotion and inhibition of SNARE assembly; however, the promotion process is the more dominant of the two.

Munc18-1 participates in the regulation of synaptic plasticity, neurodevelopment and neuroendocrine cell function. Munc18-1 can function to regulate brain-derived neurotrophic factors, participate in the development of synapses and affect cognitive functions $(23,24)$. Synaptic plasticity is the basic 
Table I. Abnormal expression and pathogenic mechanism of Munc18-1 in different neurological disorders.

\begin{tabular}{|c|c|c|c|c|}
\hline First author, year & Neurological disorders & $\begin{array}{l}\text { Munc18-1 } \\
\text { expression }\end{array}$ & Pathogenic mechanism & (Refs.) \\
\hline $\begin{array}{l}\text { Romaniello et al, 2015; } \\
\text { Ortega-Moreno } \\
\text { et al,2016; } \\
\text { Miyamoto } \text { et al, } 2017\end{array}$ & Epileptic encephalopathy & Decreased & $\begin{array}{l}\text { GABA-ergic disorder } \\
\text { Impaired synaptic plasticity }\end{array}$ & $(17,43,73)$ \\
\hline Toonen et al, 2006 & Autism & Decreased & $\begin{array}{l}\text { Glutamatergic and GABA-ergic disorder } \\
\text { Neurodevelopmental disorders }\end{array}$ & (71) \\
\hline $\begin{array}{l}\text { Ramos-Miguel } \\
\text { et al, } 2015 \\
\text { Behan } \text { et al, } 2009 \\
\text { Urigüen } \text { et al, } 2013\end{array}$ & Schizophrenia & Increased & Dopaminergic disorder & $(19,46,75)$ \\
\hline Lanoue et al, 2019 & Parkinson's disease & Decreased & $\begin{array}{l}\text { Regulates } \alpha \text {-synaptic protein } \\
\text { replication and aggregation } \\
\text { Impaired synaptic plasticity }\end{array}$ & (78) \\
\hline $\begin{array}{l}\text { Ramos-Miguel } \\
\text { et al, } 2015\end{array}$ & Alzheimer's disease & Decreased & $\begin{array}{l}\text { Highly phosphorylated Tau protein } \\
\text { Impaired synaptic plasticity } \\
\text { GABA-ergic disorder }\end{array}$ & (82) \\
\hline Linker et al, 2009 & Multiple sclerosis & Increased & Glutamate excitotoxicity & (48) \\
\hline Murphy et al, 2015 & Duchenne's muscular dystrophy & Decreased & Unclear & (49) \\
\hline Sleat et al, 2017 & Neuronal ceroid lipofuscinosis & Decreased & Unclear & (50) \\
\hline
\end{tabular}

GABA, $\gamma$-aminobutyric acid.

process responsible for learning and memory (25). Previous studies have determined that the expression of Munc18-1 was decreased in the hippocampus of STXBP1 heterozygous knockout mice. This impaired synaptic plasticity, synaptic vesicle release rate and vesicle pool production, leading to impaired learning and memory (26-28). Activation of the diacylglycerol/protein kinase $\mathrm{C}$ ( $\mathrm{PKC}$ ) pathway can enhance neuronal synaptic transmission $(29,30)$. In addition to the phosphorylation of Munc18-1, which transfers synaptic vesicles to active regions, the PKC pathway further accelerates the assembly of the SNARE complex $(31,32)$. Synaptotagmin-1 is a synaptic-associated protein, the phosphorylation of which is an important step in the PKC pathway of synaptic transmission (33). Together with Munc18-1 phosphorylation, they represent an important aspect of synaptic plasticity, enhancing synaptic transmission and promoting neurotransmitter release $(34,35)$.

The functional destruction of Munc18-1 affects the development of the cerebral cortex, which may cause neurodevelopmental disorders by affecting brain-derived neurotrophic factor and the downstream tropomyosin receptor kinase B pathway (36). While the functions of the exocytotic proteins SNARE and Munc18-1 have garnered increasing attention, studies have demonstrated that Munc18-1 promotes insulin secretion by interacting with SNARE, and the decline of its expression leads to insulin secretion disorders $(37,38)$. Thyroid hormone is very important for normal brain development. Previous studies have determined that in mice with mild spatial cognitive impairment, the spatial learning and memory of old and middle-aged mice decreases. Additionally, the expression of serum thyroxine is decreased in these animals, which increases Munc18-1 levels, demonstrating a negative correlation and indicating that Munc18-1 negatively regulates the role of thyroxine in brain development (39-41).

\section{Association between Munc18-1 and neurological disorders}

Munc18-1 is a key regulatory protein of transmission and its physiological function has been increasingly studied (6). The abnormal expression of Munc18-1 is involved in the pathogenesis of various neurological diseases and is closely associated with epileptic encephalopathy, autism, schizophrenia (SCZ), Parkinson's disease, Alzheimer's disease (AD), multiple sclerosis (MS), Duchenne's muscular dystrophy and neuronal ceroid lipofuscinosis (Table I) (42-50).

Munc18-1 and epileptic encephalopathy. Epileptic encephalopathy is a severe brain dysfunction with poor prognosis that is commonly observed in infants and children, and is often characterized by frequent seizures, intellectual disability and dyskinesia (51). The etiology of epileptic encephalopathy is not completely understood, and it has been reported that $\sim 70 \%$ of epileptic encephalopathy cases are associated with genetic factors $(52,53)$. An increasing number of studies have reported that STXBP1exhibitsmultiple mutation types in severe epileptic encephalopathy, including missense and splicing mutations, which lead to single protein insufficient ploidy, impaired 
protein stability, unbalanced cortical excitement, impaired synaptic plasticity and GABA-ergic transmission barriers that adversely affect learning and memory $(28,43)$. The treatment of epileptic encephalopathy is challenging. However, studies have reported that drugs such as Keppra and adreno-corticotropic-hormone can prevent epilepsy to a certain extent, exerting no significant effect on other clinical symptoms, such as psychomotor disability and cognitive dysfunction (54-57).

Ohtahara syndrome, also known as epileptic encephalopathy in early infants, is a severe seizure related to stunting and mental disability. Its other neurological characteristics include autism spectrum disorder and dyskinesia (14). STXBP1 is the pathogenic gene of Ohtahara syndrome. Saitsu et al (58) identified that STXBP1 was mutated in children with this syndrome in 2008. With research on genetic diagnosis, an increasing number of studies have identified gene mutations in Ohtahara syndrome $(59,60)$. A previous study demonstrated that the clinical manifestations in children $<3$ months were accompanied with tonic spasm, and the electroencephalograms of most children exhibited burst suppression in Ohtahara syndrome (61). The main clinical manifestations of West syndrome include nodding spasm, high irregularities in electroencephalograms and severe intellectual disability. Since Otsuka et al (62) first reported the STXBP1 mutation in West syndrome in 2010, following studies then identified STXBP1 nonsense and splice site mutations through clinical studies (63). In addition, STXBP1 mutations were identified in Dravet syndrome and Lennox-Gastaut syndrome, although evidence of these mutations in Ohtahara syndrome is not sufficient $(64,65)$. Rett syndrome (RTT) is a neurodevelopmental disorder typically caused by mutations of methyl-CpG binding protein 2 (MECP2). However, Yuge et al (66) reported in 2018 that a STXBP1 mutation was detected in a case diagnosed with RTT. Moreover, a 9-year-old female with RTT and severe cognitive impairment exhibited no MECP2 mutation, but a STXBP1mutation was identified. MECP2 gene mutations result in the decrease of glutamate and gamma-aminobutyric acid receptor densities (17). It is hypothesized that deficits in synaptic plasticity may, to some extent, indicate an association between MECP2 and the pathogenicity of STXBP1 mutations (17).

Munc18-1 and autism. Autism is a common neurodevelopmental disorder with a high disability rate and strong genetic basis (67). At present, while almost all patients with STXBP1 mutations exhibit certain clinical phenotypes, including seizures and mental disabilities, $\sim 20 \%$ have autism and can demonstrate increased aggressive behavior $(68,69)$. A study by Dachtler et al (45) used a synaptic adhesion protein $\alpha$-neurexin II-deficient mouse model of autism, and through protein quantitative analysis, detemined that Munc18-1 encoded by STXBP1 was significantly reduced in the hippocampus of mice. Synaptic adhesion proteins serve a key role in the formation and maintenance of synapses, and are involved in mediating synaptic plasticity (70). Decreased expression of Munc18-1 regulates the expression of $\alpha$-neurexin II, impairs synaptic plasticity and participates in the occurrence of autism (71). In a mouse model of heterozygous STXBP1 knockout, it was revealed that the number of vesicles in the synaptic active region was reduced, and glutamatergic and GABA-ergic transmission were impaired. These mice demonstrated increased anxiety and impaired emotional learning (72). In addition, Miyamoto et al (73) reported that the normalization of excitatory synaptic transmission in STXBP1 knockout mice, which exhibit various degrees of cognitive impairment and aggressiveness, improved Munc18-1 haploid deficiency-related aggression. It is speculated that Munc18-1 may be involved in the clinical phenotype of autism, potentially providing novel treatment methods.

Munc18-1 and SCZ. SCZ is a severe mental disorder with unclear causes. The main hypotheses suggest that it is mediated by overactive dopamine activity, 5 -hydroxytryptamine and norepinephrine neural pathway dysfunction, excitatory amino acid dysfunction and the neuropeptide hypothesis. Neuropeptide protein is involved in the process of neurodevelopment, and low expression is involved in SCZ through the release of glutamate and $\gamma$-aminobutyric acid) (74). A proteomic analysis of the brain tissue of patients with SCZ by Behan et al (46) determined that Munc18-1 was highly expressed. Compared with patients who did not use anti-SCZ drugs, Munc18-lexpression in patients who used these drugs decreased. Additionally, in a mouse model of SCZ utilized by Urigüen et al (75), a high expression of Munc18-1 was identified in the gray matter of the brain. Similarly, a high expression of Munc18-1 was detected in STXBP1 transgenic mice, which exhibited symptoms of SCZ, decreased expressions of dopamine receptors, decreased expressions of membrane transporters and decreased brain gray matter volume (75). Munc18-1 participates in the pathogenesis of SCZ by regulating excitatory neurotransmitters; however, the cause and mechanism of associated brain volume reduction is unclear.

Munc18-1 and neurodegenerative diseases. Parkinson's disease is a degenerative disease of the nervous system. Previous studies have demonstrated that the abnormal expression of $\alpha$-synuclein and self-replication aggregation serve a key role in the degenerative changes of Parkinson's disease neurons $(76,77)$. Munc18-1 serves other biological functions in addition to regulating neurotransmitter transmission. For example, Lanoue et al (78) revealed that Munc18-1 participates in various neurodegenerative diseases, including Parkinson's disease, by controlling the self-replication and aggregation of $\alpha$-synuclein. Neurodevelopment in epileptic encephalopathy may also be affected by synuclein (78). The physiological functions of $\alpha$-synuclein are complex; $\alpha$-synuclein self-replication and aggregation inhibit exocytosis, affect vesicle secretion and regulate synaptic plasticity $(76,79)$. A previous study revealed that Munc18-1 acts as a chaperone to regulate the replication and aggregation of $\alpha$-synuclein, the decreased expression of Munc18-1 increases the aggregation tendency of $\alpha$-synuclein, while the increased expression of Munc18-1 reverses this affect (80). At present, the specific pathways underlying the Munc18-1-associated regulation of $\alpha$-synuclein are unclear, and further research is required to further understand and effectively treat Parkinson's disease.

$\mathrm{AD}$ is a progressive neurodegenerative disorder with an insidious onset. Its etiology includes the deposition of abnormal amyloid $\beta$ extracellular plaques and intracellular 
neurofibrillary tangles containing hyperphosphorylated Tau protein, which lead to impaired synaptic plasticity (81). Previous studies have demonstrated that at the GABAergic presynaptic inhibition terminal, the expression of the Munc18-1 long splice variant is closely associated with cognitive function. Furthermore, the deletion of the Munc18-1 long splice variant increases the risk of AD $(47,82)$. In a study assessing the effect of pomegranate on an AD mouse model, it was determined that pomegranate can enhance synaptic plasticity by increasing the expression of Munc18-1, SNAP25 and synaptophysin, improving spatial learning impairment in mice (83). Additionally, a study has determined that when comparing the brain tissue of healthy individuals and deceased patients with AD of the same age, brain tissue following AD-associated death is rich in highly phosphorylated Tau protein and Munc18-1 is abnormally expressed (84). The current treatment methods used for patients with AD remain poor, and further understanding of Munc18-1 may provide a novel target.

Munc18-1 and other diseases, including MS, Duchenne muscular dystrophy and neuronal ceroid lipofuscinosis. The most common type of white matter injury is demyelination, which includes myelin loss and axonal abnormalities (85). MS is an autoimmune disease characterized by the inflammatory demyelination of white matter in the central nervous system (86). A previous study reported that in a murine model of multiple sclerosis, the expression of Munc18-1 and axon structural protein $\alpha$-internexin increases, and the expression of glutamate decarboxylase decreases, mediating immunity to myelin damage (48). An increased expression of $\alpha$-internexin, axon disintegration, the Munc18-1 regulation of glutamatergic transmission and glutamate excitotoxicity further increase axon damage (87). However, there are few studies that assessMunc18-1 in MS and the specific underlying pathogenic mechanism remains unknown.

Duchenne muscular dystrophy is a disease that affects the neuromuscular system. Progressive skeletal muscle atrophy is the main complication, and developmental cognitive deficits and behavioral abnormalities are its main clinical features (88). Murphy et al (49) performed proteomics on the brain tissue of mice with Duchenne muscular dystrophy, the results of which revealed that the expression of Munc18-1 was significantly decreased. A further study revealed that the expression of Munc18-1 was significantly decreased in the brains of children with neuronal ceroid lipofuscinosis (50). These studies indicate that Munc18-1 may be involved in the pathogenesis of Duchenne muscular dystrophy and neurodegenerative lysosomal diseases. Combined with the characteristics of these diseases, impaired synaptic plasticity and neurodevelopmental pathways serve an important role in these diseases. Munc18-1 may participate in the pathogenesis of disease by regulating synaptic plasticity and neurodevelopment; however there are few related studies to confirm this, and the specific underlying mechanisms require further exploration.

\section{Conclusion and future perspectives}

Munc18-1 has powerful biological functions and can regulate the balance of synaptic excitatory neurotransmitter and inhibitory neurotransmitter transmission, and mediate disease processes at increased or decreased expressions. Decreased Munc18-1 expression also damages synaptic plasticity and affects learning and memory. Neuronal transmission requires the participation of multiple neurotransmitters, and Munc18-1 regulates neurotransmitter transmission by regulating the SNARE complex. This process is complicated and requires the participation of multiple regulatory proteins. The relationship between the expression of Munc18-1 and specific neurotransmitter regulation mechanisms remains unclear and requires further study. An enhanced understanding of the function of Munc18-1 may elucidate novel therapeutic strategies for the treatment of neurological diseases.

\section{Acknowledgements}

Not applicable.

\section{Funding}

The present study was supported by the National Key R\&D Program of China (grant nos. 2017YFA 0104201 and 2017YFA 0104200), the National Science Foundation of China (grant nos. 82071353, 82001593, 81330016, 81630038 and 81771634), and the Science and Technology Bureau of Chengdu City (grant no. 2015-HM01-00424-SF).

\section{Availability of data and materials}

Not applicable.

\section{Authors' contributions}

FT and DX conceived the present study. FT, DX, LC and XL provided the software. FT, DX, HG and XL provided the study resources. HG and XL generated the figure. FT and DX drafted the manuscript. FT, DX, HG, HG and XL reviewed and edited the manuscript. XL supervised the study. DL and XL confirm the authenticity of all the data. All authors read and approved the final manuscript.

\section{Ethics approval and consent to participate}

Not applicable.

\section{Patient consent for publication}

Not applicable.

\section{Competing interests}

All authors declare that they have no competing interests.

\section{References}

1. Brose N, Brunger A, Cafiso D, Chapman ER, Diao J, Hughson FM, Jackson MB, Jahn R, Lindau M, Ma C, et al: Synaptic vesicle fusion: today and beyond. Nat Struct Mol Biol 26: 663-668, 2019.

2. Snead D and Eliezer D: Intrinsically disordered proteins in synaptic vesicle trafficking and release. J Biol Chem 294: 3325-3342, 2019 
3. Ruete MC, Zarelli VEP, Masone D, de Paola M, Bustos DM and Tomes $\mathrm{CN}$ : A connection between reversible tyrosine phosphorylation and SNARE complex disassembly activity of $\mathrm{N}$-ethylmaleimide-sensitive factor unveiled by the phosphomimetic mutant N-ethylmaleimide-sensitive factor-Y83E. Mol Hum Reprod 25: 344-358, 2019.

4. Bombardier JP and Munson M: Three steps forward, two steps back: Mechanistic insights into the assembly and disassembly of the SNARE complex. Curr Opin Chem Biol 29: 66-71, 2015.

5. Kavanagh DM, Smyth AM, Martin KJ, Dun A, Brown ER, Gordon S, Smillie KJ, Chamberlain LH, Wilson RS, Yang L, et al: A molecular toggle after exocytosis sequesters the presynaptic syntaxin1a molecules involved in prior vesicle fusion. Nat Commun 5: 5774, 2014.

6. Jorgačevski J and Zorec R: Munc18-1, exocytotic fusion pore regulation and local membrane anisotropy. Commun Integr Biol 5: 74-77, 2012.

7. Han GA, Malintan NT, Saw NM, Li L, Han L, Meunier FA, Collins BM and Sugita S: Munc18-1 domain-1 controls vesicle docking and secretion by interacting with syntaxin-1 and chaperoning it to the plasma membrane. Mol Biol Cell 22: 4134-4149, 2011.

8. Graham ME, Prescott GR, Johnson JR, Jones M, Walmesley A, Haynes LP, Morgan A, Burgoyne RD and Barclay JW: Structurefunction study of mammalian Munc18-1 and C. elegans UNC-18 implicates domain $3 \mathrm{~b}$ in the regulation of exocytosis. PLoS One 6: e17999, 2011

9. Rizo J and Südhof TC: The membrane fusion enigma: SNAREs, Sec1/Munc18 proteins, and their accomplices--guilty as charged? Annu Rev Cell Dev Biol 28: 279-308, 2012.

10. Pons-Vizcarra M, Kurps J, Tawfik B, Sørensen JB, van Weering JRT and Verhage M: MUNC18-1 regulates the submembrane F-actin network, independently of syntaxin1 targeting, via hydrophobicity in $\beta$-sheet 10 . J Cell Sci 132 : jcs234674, 2019. https://doi.org/10.1242/jcs.234674.

11. Hamdan FF, Piton A, Gauthier J, Lortie A, Dubeau F, Dobrzeniecka S, Spiegelman D, Noreau A, Pellerin S, Côté M, et al: De novo STXBP1 mutations in mental retardation and nonsyndromic epilepsy. Ann Neurol 65: 748-753, 2009.

12. Deciphering Developmental Disorders Study: Prevalence and architecture of de novo mutations in developmental disorders. Nature 542: 433-438, 2017.

13. Weckhuysen S, Holmgren P, Hendrickx R, Jansen AC, Hasaerts D, Dielman C, de Bellescize J, Boutry-Kryza N, Lesca G, Von Spiczak S, et al: Reduction of seizure frequency after epilepsy surgery in a patient with STXBP1 encephalopathy and clinical description of six novel mutation carriers. Epilepsia 54: e74-e80, 2013.

14. Kovacevic J, Maroteaux G, Schut D, Loos M, Dubey M, Pitsch J, Remmelink E, Koopmans B, Crowley J, Cornelisse LN, et al: Protein instability, haploinsufficiency, and cortical hyper-excitability underlie STXBP1 encephalopathy. Brain 141: 1350-1374, 2018.

15. Eisemann TJ, Allen F, Lau K, Shimamura GR, Jeffrey PD and Hughson FM: The Sec1/Munc18 protein Vps45 holds the Qa-SNARE Tlg2 in an open conformation. eLife 9: e60724, 2020.

16. Lee S, Shin J, Jung Y, Son H, Shin J, Jeong C, Kweon DH and Shin YK: Munc18-1 induces conformational changes of syntaxin-1 in multiple intermediates for SNARE assembly. Sci Rep 10: 11623, 2020.

17. Romaniello R, Saettini F, Panzeri E, Arrigoni F, Bassi MT and Borgatti R: A de-novo STXBP1 gene mutation in a patien showing the Rett syndrome phenotype. Neuroreport 26: 254-257, 2015.

18. Gil-Pisa I, Munarriz-Cuezva E, Ramos-Miguel A, Urigüien L, Meana JJ and García-Sevilla JA: Regulation of munc18-1 and syntaxin-1A interactive partners in schizophrenia prefrontal cortex: Down-regulation of munc18-1a isoform and $75 \mathrm{kDaSNARE}$ complex after antipsychotic treatment. Int J Neuropsychopharmacol 15: 573-588, 2012.

19. Ramos-Miguel A, Beasley CL, Dwork AJ, Mann JJ, Rosoklija G, Barr AM and Honer WG: Increased SNARE Protein-Protein Interactions in Orbitofrontal and Anterior Cingulate Cortices in Schizophrenia. Biological Psychiatry 78: 361-373, 2015.

20. Zhou P, Pang ZP, Yang X, Zhang Y, Rosenmund C, Bacaj T and Südhof TC: Syntaxin-1 N-peptide and Habc-domain perform distinct essential functions in synaptic vesicle fusion. EMBO J 32: 159-171, 2013.
21. Jiang X, Zhang Z, Cheng K, Wu Q, Jiang L, Pielak GJ, Liu M and Li C: Membrane-mediated disorder-to-order transition of SNAP25 flexible linker facilitates its interaction with syntaxin-1 and SNARE-complex assembly. FASEB J 33: 79857994, 2019

22. Sitarska E, Xu J, Park S, Liu X, Quade B, Stepien K, Sugita K, Brautigam CA, Sugita S and Rizo J: Autoinhibition of Munc18-1 modulates synaptobrevin binding and helps to enable Munc13dependent regulation of membrane fusion. eLife 6: e24278, 2017.

23. Lee YI, Kim YG, Pyeon HJ, Ahn JC, Logan S, Orock A, Joo KM, Lőrincz A and Deák F: Dysregulation of the SNARE-binding protein Munc18-1 impairs BDNF secretion and synaptic neurotransmission: A novel interventional target to protect the aging brain. Geroscience 41: 109-123, 2019.

24. Peng Y, Lee J, Rowland K, Wen Y, Hua H, Carlson N, Lavania S, Parrish JZ and Kim MD: Regulation of dendrite growth and maintenance by exocytosis. J Cell Sci 128: 4279-4292, 2015.

25. De Pittà M, Brunel N and Volterra A: Astrocytes: Orchestrating synaptic plasticity? Neuroscience 323: 43-61, 2016.

26. Lammertse HCA, van Berkel AA, Iacomino M, Toonen RF, Striano P, Gambardella A, Verhage M and Zara F: Homozygous STXBP1 variant causes encephalopathy and gain-of-function in synaptic transmission. Brain 143: 441-451, 2020

27. Meijer M, Cijsouw T, Toonen RF and Verhage M: Synaptic effects of Munc18-1 alternative splicing in excitatory hippocampal neurons. PLoS One 10: e0138950, 2015.

28. Orock A, Logan S and Deak F: Munc18-1 haploinsufficiency impairs learning and memory by reduced synaptic vesicular release in a model of Ohtahara syndrome. Mol Cell Neurosci 88: 33-42, 2018.

29. Wang CC, Weyrer C, Paturu M, Fioravante D and Regehr WG: Calcium-dependent protein kinase $\mathrm{C}$ is not required for posttetanic potentiation at the hippocampal CA3 to CA1 synapse. J Neurosci 36: 6393-6402, 2016.

30. Galván EJ, Cosgrove KE, Mauna JC, Card JP, Thiels E, Meriney SD and Barrionuevo G: Critical involvement of postsynaptic protein kinase activation in long-term potentiation at hippocampal mossy fiber synapses on CA3 interneurons. J Neurosci 30: 2844-2855, 2010.

31. Barclay JW, Craig TJ, Fisher RJ, Ciufo LF, Evans GJ, Morgan A and Burgoyne RD: Phosphorylation of Munc18 by protein kinase $\mathrm{C}$ regulates the kinetics of exocytosis. J Biol Chem 278 : 10538-10545, 2003.

32. Wierda KD, Toonen RF, de Wit H, Brussaard AB and Verhage M: Interdependence of PKC-dependent and PKC-independent pathways for presynaptic plasticity. Neuron 54: 275-290, 2007.

33. Cijsouw T, Weber JP, Broeke JH, Broek JA, Schut D, Kroon T, Saarloos I, Verhage M and Toonen RF: Munc18-1 redistributes in nerve terminals in an activity- and PKC-dependent manner. J Cell Biol 204: 759-775, 2014.

34. de Jong AP, Meijer M, Saarloos I, Cornelisse LN, Toonen RF, Sørensen JB and Verhage M: Phosphorylation of synaptotagmin-1 controls a post-priming step in PKC-dependent presynaptic plasticity. Proc Natl Acad Sci USA 113: 5095-5100, 2016.

35. Genc O, Kochubey O, Toonen RF, Verhage $M$ and Schneggenburger R: Munc18-1 is a dynamically regulated PKC target during short-term enhancement of transmitter release. eLife 3: e01715, 2014.

36. Hamada N, Iwamoto I, Tabata H and Nagata KI: MUNC18-1 gene abnormalities are involved in neurodevelopmental disorders through defective cortical architecture during brain development. Acta Neuropathol Commun 5: 92, 2017.

37. Lang H, Ai Z, You Z, Wan Y, Guo W, Xiao J and Jin X: Characterization of miR-218/322-Stxbp1 pathway in the process of insulin secretion. J Mol Endocrinol 54: 65-73, 2015.

38. Oh E, Kalwat MA, Kim MJ, Verhage M and Thurmond DC: Munc18-1 regulates first-phase insulin release by promoting granule docking to multiple syntaxin isoforms. J Biol Chem 287: 25821-25833, 2012

39. Cao L, Wang F, Yang QG, Jiang W, Wang C, Chen YP and Chen GH: Reduced thyroid hormones with increased hippocampal SNAP-25 and Munc18-1 might involve cognitive impairment during aging. Behav Brain Res 229: 131-137, 2012.

40. Cao L, Jiang W, Wang F, Yang QG, Wang C, Chen YP and Chen GH: The reduced serum free triiodothyronine and increased dorsal hippocampal SNAP-25 and Munc18-1 had existed in middle-aged CD-1 mice with mild spatial cognitive impairment. Brain Res 1540: 9-20, 2013. 
41. Zevenbergen C, Groeneweg S, Swagemakers SMA, de Jong A, Medici-Van den Herik E, Rispens M, Klootwijk W, Medici M, de Rijke YB, Meima ME, et al: Functional analysis of genetic variation in the SECIS element of thyroid hormone activating type 2 deiodinase. J Clin Endocrinol Metab 104: 1369-1377, 2019.

42. Grone BP, Marchese M, Hamling KR, Kumar MG, Krasniak CS, Sicca F, Santorelli FM, Patel M and Baraban SC: Epilepsy, behavioral abnormalities, and physiological comorbidities in syntaxin-binding protein 1 (STXBP1) mutant Zebrafish. PLoS One 11: e0151148, 2016.

43. Ortega-Moreno L, Giráldez BG, Verdú A, García-Campos O, Sánchez-Martín G, Serratosa JM and Guerrero-López R: Novel mutation in STXBP1 gene in a patient with non-lesional Ohtahara syndrome. Neurologia 31: 523-527, 2016.

44. Dachtler J, Ivorra JL, Rowland TE, Lever C, Rodgers RJ and Clapcote SJ: Heterozygous deletion of $\alpha$-neurexin I or $\alpha$-neurexin II results in behaviors relevant to autism and schizophrenia. Behav Neurosci 129: 765-776, 2015.

45. Dachtler J, Glasper J, Cohen RN, Ivorra JL, Swiffen DJ, Jackson AJ, Harte MK, Rodgers RJ and Clapcote SJ: Deletion of $\alpha$-neurexin II results in autism-related behaviors in mice. Transl Psychiatry 4: e484, 2014.

46. Behan AT, Byrne C, Dunn MJ, Cagney G and Cotter DR: Proteomic analysis of membrane microdomain-associated proteins in the dorsolateral prefrontal cortex in schizophrenia and bipolar disorder reveals alterations in LAMP, STXBP1 and BASP1 protein expression. Mol Psychiatry 14: 601-613, 2009.

47. Lanoue V, Chai YJ, Brouillet JZ, Weckhuysen S, Palmer EE, Collins BM and Meunier FA: STXBP1 encephalopathy: Connecting neurodevelopmental disorders with $\alpha$-synucleinopathies? Neurology 93: 114-123, 2019.

48. Linker RA, Brechlin P, Jesse S, Steinacker P, Lee DH, Asif AR, Jahn O, Tumani H, Gold R and Otto M: Proteome profiling in murine models of multiple sclerosis: Identification of stage specific markers and culprits for tissue damage. PLoS One 4: e7624, 2009.

49. Murphy S, Zweyer M, Henry M, Meleady P, Mundegar RR Swandulla D and Ohlendieck K: Label-free mass spectrometric analysis reveals complex changes in the brain proteome from the mdx-4cv mouse model of Duchenne muscular dystrophy. Clin Proteomics 12: 27, 2015.

50. Sleat DE, Tannous A, Sohar I, Wiseman JA, Zheng H, Qian M, Zhao C, Xin W, Barone R, Sims KB, et al: Proteomic analysis of brain and cerebrospinal fluid from the three major forms of neuronal ceroid lipofuscinosis reveals potential biomarkers. J Proteome Res 16: 3787-3804, 2017.

51. Scheffer IE, Berkovic S, Capovilla G, Connolly MB, French J, Guilhoto L, Hirsch E, Jain S, Mathern GW, Moshé SL, et al: ILAE classification of the epilepsies: Position paper of the ILAE Commission for Classification and Terminology. Epilepsia 58: 512-521, 2017.

52. Hunter MB, Yoong M, Sumpter RE, Verity K, Shetty J, McLellan A, Jones J, Quigley A, Tallur KK and Chin RFM: Neurobehavioral problems in children with early-onset epilepsy: A population-based study. Epilepsy Behav 93: 87-93, 2019.

53. Mercimek-Mahmutoglu S, Patel J, Cordeiro D, Hewson S, Callen D, Donner EJ, Hahn CD, Kannu P, Kobayashi J, Minassian BA, et al: Diagnostic yield of genetic testing in epileptic encephalopathy in childhood. Epilepsia 56: 707-716, 2015.

54. Liu S, Wang L, Cai XT, Zhou H, Yu D and Wang Z: Therapeutic benefits of ACTH and levetiracetam in STXBP1 encephalopathy with a de novo mutation: A case report and literature review. Medicine (Baltimore) 97: e0663, 2018.

55. Li T, Cheng M, Wang J, Hong S, Li M, Liao S, Xie L and Jiang L: De novo mutations of STXBP1 in Chinese children with early onset epileptic encephalopathy. Genes Brain Behav 17: e12492, 2018.

56. Stamberger H, Weckhuysen S and De Jonghe P: STXBP1 as a therapeutic target for epileptic encephalopathy. Expert Opin Ther Targets 21: 1027-1036, 2017.

57. Dilena R, Striano P, Traverso M, Viri M, Cristofori G, Tadini L, Barbieri S, Romeo A and Zara F: Dramatic effect of levetiracetam in early-onset epileptic encephalopathy due to STXBP1 mutation. Brain Dev 38: 128-131, 2016.

58. Saitsu H, Kato M, Mizuguchi T, Hamada K, Osaka H, Tohyama J, Uruno K, Kumada S, Nishiyama K, Nishimura A, et al: De novo mutations in the gene encoding STXBP1 (MUNC18-1) cause early infantile epileptic encephalopathy. Nat Genet 40: 782-788, 2008 .
59. Lee S, Kim SH, Kim B, Lee ST, Choi JR, Kim HD, Lee JS and Kang HC: Genetic diagnosis and clinical characteristics by etiological classification in early-onset epileptic encephalopathy with burst suppression pattern. Epilepsy Res 163: 106323, 2020.

60. Mitta N, Menon RN, McTague A, Radhakrishnan A, Sundaram S, Cherian A, Madhavilatha GK, Mannan AU, Nampoothiri S and Thomas SV: Genotype-phenotype correlates of infantile-onset developmental \& epileptic encephalopathy syndromes in South India: A single centre experience. Epilepsy Res 166: 106398, 2020.

61. Di Meglio C, Lesca G, Villeneuve N, Lacoste C, AbidiA, Cacciagli P, Altuzarra C, Roubertie A, Afenjar A, Renaldo-Robin F, et al: Epileptic patients with de novo STXBP1 mutations: Key clinical features based on 24 cases. Epilepsia 56: 1931-1940, 2015.

62. Otsuka M, Oguni H, Liang JS, Ikeda H, Imai K, Hirasawa K, Imai K, Tachikawa E, Shimojima K, Osawa M, et al: STXBP1 mutations cause not only Ohtahara syndrome but also West syndrome--result of Japanese cohort study. Epilepsia 51: 2449-2452, 2010.

63. Boutry-Kryza N,Labalme A, Ville D, de Bellescize J, Touraine R, Prieur F, Dimassi S, Poulat AL, Till M, Rossi M, et al: Molecular characterization of a cohort of 73 patients with infantile spasms syndrome. Eur J Med Genet 58: 51-58, 2015.

64. Steel D, Symonds JD, Zuberi SM and Brunklaus A: Dravet syndrome and its mimics: Beyond SCN1A. Epilepsia 58: 1807-1816, 2017.

65. Mastrangelo M: Lennox-Gastaut Syndrome: A state of the art review. Neuropediatrics 48: 143-151, 2017.

66. Yuge K, Iwama K, Yonee C, Matsufuji M, Sano N, Saikusa T, Yae Y, Yamashita Y, Mizuguchi T, Matsumoto N, et al: A novel STXBP1 mutation causes typical Rett syndrome in a Japanese girl. Brain Dev 40: 493-497, 2018.

67. Li J, Lin X, Wang M, Hu Y, Xue K, Gu S, Lv L, Huang S and Xie W: Potential role of genomic imprinted genes and brain developmental related genes in autism. BMC Med Genomics 13: $54,2020$.

68. Stamberger $\mathrm{H}$, Nikanorova $\mathrm{M}$, Willemsen $\mathrm{MH}$, Accorsi $\mathrm{P}$, Angriman M, Baier H, Benkel-Herrenbrueck I, Benoit V, Budetta M, Caliebe A, et al: STXBP1 encephalopathy: A neurodevelopmental disorder including epilepsy. Neurology 86: 954-962, 2016.

69. Jiang YH, Yuen RK, Jin X, Wang M, Chen N, Wu X, Ju J, Mei J, Shi Y, He M, et al: Detection of clinically relevant genetic variants in autism spectrum disorder by whole-genome sequencing. Am J Hum Genet 93: 249-263, 2013.

70. Dudanova I, Tabuchi K, Rohlmann A, Südhof TC and Missler M: Deletion of $\alpha$-neurexins does not cause a major impairment of axonal pathfinding or synapse formation. J Comp Neurol 502: 261-274, 2007.

71. Toonen RF, Wierda K, Sons MS, de Wit H, Cornelisse LN, Brussaard A, Plomp JJ and Verhage M: Munc18-1 expression levels control synapse recovery by regulating readily releasable pool size. Proc Natl Acad Sci USA 103: 18332-18337, 2006.

72. 7Chamma I, Sainlos M and Thoumine O: Biophysical mechanisms underlying the membrane trafficking of synaptic adhesion molecules. Neuropharmacology 169: 107555, 2020.

73. Miyamoto H, Shimohata A, Abe M, Abe T, Mazaki E, Amano K, Suzuki T, Tatsukawa T, Itohara S, Sakimura K, et al: Potentiation of excitatory synaptic transmission ameliorates aggression in mice with Stxbp1 haploinsufficiency. Hum Mol Genet 26: 4961-4974, 2017.

74. Valton V, Romaniuk L, Douglas Steele J, Lawrie S and Seriès P: Comprehensive review: Computational modelling of schizophrenia. Neurosci Biobehav Rev 83: 631-646, 2017.

75. Urigüen L, Gil-Pisa I, Munarriz-Cuezva E, Berrocoso E, Pascau J, Soto-Montenegro ML, Gutiérrez-Adán A, Pintado B, Madrigal JL, CastroE, et al: Behavioral, neurochemical and morphological changes induced by the overexpression of munc18-1a in brain of mice: Relevance to schizophrenia. Transl Psychiatry 3: e221, 2013.

76. Kim ST, Moon W, Chae Y, Kim YJ, Lee H and Park HJ: The effect of electroaucpuncture for 1-methyl-4-phenyl-1,2,3,6tetrahydropyridine-induced proteomic changes in the mouse striatum. J Physiol Sci 60: 27-34, 2010.

77. Burré J, Sharma M and Südhof TC: Cell biology and pathophysiology of $\alpha$-synuclein. Cold Spring Harb Perspect Med 8: a024091, 2018. 
78. Lanoue V, Chai YJ, Brouillet JZ, Weckhuysen S, Palmer EE, Collins BM and Meunier FA: STXBP1 encephalopathy: Connecting neurodevelopmental disorders with alpha-synucleinopathies? Neurology 93: 114-123, 2019

79. Huang CC, Chiu TY, Lee TY, Hsieh HJ, Lin CC and Kao LS Soluble $\alpha$-synuclein facilitates priming and fusion by releasing $\mathrm{Ca}^{2+}$ from the thapsigargin-sensitive $\mathrm{Ca}^{2+}$ pool in PC12 cells. J Cell Sci 131: jcs213017, 2018. https://doi.org/10.1242/jcs.213017.

80. Chai YJ, Sierecki E, Tomatis VM, Gormal RS, Giles N, Morrow IC, Xia D, Götz J, Parton RG, Collins BM, et al: Munc18-1 is a molecular chaperone for $\alpha$-synuclein, controlling its self-replicating aggregation. J Cell Biol 214: 705-718, 2016.

81. Braidy N, Essa MM, Poljak A, Selvaraju S, Al-Adawi S Manivasagm T, Thenmozhi AJ, Ooi L, Sachdev P and Guillemin GJ: Consumption of pomegranates improves synaptic function in a transgenic mice model of Alzheimer's disease. Oncotarget 7: 64589-64604, 2016.

82. Ramos-Miguel A, Hercher C, Beasley CL, Barr AM, Bayer TA, Falkai P, Leurgans SE, Schneider JA, Bennett DA and Honer WG: Loss of Munc18-1 long splice variant in GABAergic terminals is associated with cognitive decline and increased risk of dementia in a community sample. Mol Neurodegener 10: 65, 2015.

83. Liu X, Hao W, Qin Y, Decker Y, Wang X, Burkart M, Schötz K, Menger MD, Fassbender K and Liu Y: Long-term treatment with Ginkgo biloba extract EGb 761 improves symptoms and pathology in a transgenic mouse model of Alzheimer's disease. Brain Behav Immun 46: 121-131, 2015.
84. Donovan LE, Higginbotham L, Dammer EB, Gearing M, Rees HD, Xia Q, Duong DM, Seyfried NT, Lah JJ and Levey AI: Analysis of a membrane-enriched proteome from postmortem human brain tissue in Alzheimer's disease. Proteomics Clin Appl 6: 201-211,2012.

85. Miyamoto N, Maki T, Shindo A, Liang AC, Maeda M, Egawa N, Itoh K, Lo EK, Lok J, Ihara M, et al: Astrocytes promote oligodendrogenesis after white matter damage via brain-derived neurotrophic factor. J Neurosci 35: 14002-14008, 2015.

86. Deiva K: Pediatric onset multiple sclerosis. Rev Neurol (Paris) 176: 30-36, 2020.

87. Werner P, Pitt D and Raine CS: Glutamate excitotoxicity--a mechanism for axonal damage and oligodendrocyte death in Multiple Sclerosis? J Neural Transm Suppl 60: 375-385, 2000.

88. Doorenweerd N, Dumas EM, Ghariq E, Schmid S, Straathof CS Roest AA, Wokke BH, van Zwet EW, Webb AG, Hendriksen JG, et al: Decreased cerebral perfusion in Duchenne muscular dystrophy patients. Neuromuscul Disord 27: 29-37, 2017.

This work is licensed under a Creative Commons Attribution-NonCommercial-NoDerivatives 4.0 International (CC BY-NC-ND 4.0) License. 